Article

\title{
Sustainability of Smallholder Agriculture in Semi-Arid Areas under Land Set-aside Programs: A Case Study from China's Loess Plateau
}

\author{
Qirui Li ${ }^{1,2, *}$, T. S. Amjath-Babu ${ }^{1}$, Peter Zander ${ }^{1}$, Zhen Liu ${ }^{3}$ and Klaus Müller ${ }^{1}$ \\ 1 Institute of Socio-Economics, Leibniz Centre for Agricultural Landscape Research (ZALF), \\ Eberswalder Straße 84, 15374 Müncheberg, Germany; Amjath.Babu@zalf.de (T.S.A.-B.); \\ Peter.Zander@zalf.de (P.Z.); kmueller@zalf.de (K.M.) \\ 2 Faculty of Agriculture and Horticulture, Humboldt University of Berlin, 12489 Berlin, Germany \\ 3 School of Business, Nanjing Normal University, 210046 Nanjing, China; 54194@njnu.edu.cn \\ * Correspondence: leolee8612@gmail.com; Tel.: +49-176-8153-1576
}

Academic Editor: Marc A. Rosen

Received: 30 November 2015; Accepted: 19 April 2016; Published: 22 April 2016

\begin{abstract}
This article analyzes agricultural sustainability in the context of land degradation, rural poverty and social inequality, taking China's Loess Hills as an example. The analysis attempts to understand the multi-dimensionality of sustainability at the farm level and its relationship with physical-socio-economic-infrastructural-technological framework conditions in the context of the land set-aside program viz. the Grain for Green Project (GGP). We developed composite indices of sustainability and its environmental, economic and social dimensions using a principal component analysis (PCA)-based weighting scheme. Regression analyses were conducted to examine the relationship between the estimated sustainability indicators and the variables representing framework conditions of knowledge, demographics, resource endowment and production techniques. The stated analysis was conducted on a dataset collected by means of household surveys in 2014 in valleys and flood plain areas in Yanhe Township. Findings reveal hidden correlations among the indicators of environmental, economic, and social pillars of sustainability. The ratio of land under the conservation program to actual farmland emerged as a key determinant of overall agricultural sustainability and its social dimension, which reaches the maximum when the ratio is around 0.56 and 0.64 , respectively. The results also show that there is need to balance off-farm and on-farm income diversification as well as highlight the role of women in ensuring the sustainability of farming households. The core achievement of the article is the definition of the thresholds for the land set-aside program and the identification of major determinants of agricultural sustainability in the rural Chinese context in particular and in rural farming communities in general.
\end{abstract}

Keywords: sustainable agriculture; framework conditions; smallholder; Grain for Green Project; composite indicators; principal component analysis

\section{Introduction}

The Chinese government has invested large sums of money in environmental restoration with multiple goals of alleviating land degradation, reducing poverty, improving livelihoods and restructuring the rural economy [1]. As one of the largest environmental restoration projects, the Grain for Green Project (GGP), also known as the Sloping Land Conversion Program (SLCP), was initiated in 1999 and continued up to 2010 with a total budget of RMB 430 billion (US\$ 63 billion; US\$ 1 was equal to RMB 6.83 in 2009). It intended to convert 14.67 million ha of farmland into forest and grassland (4.4 million of which is land with slopes exceeding $25^{\circ}$ ) and 17.3 million ha of wasteland (including 
abandoned farmland) into forest [2-4] in 25 provinces in western China. On the Loess Plateau, the GGP attributed highest priority to controlling soil erosion and reducing rural poverty by providing an annual compensation of RMB 1350 per hectare of sloping farmland (with a gradient exceeding $25^{\circ}$ ) set aside under the program [5]. However, it is not clear whether the GGP succeeded in improving rural livelihood [6-8], as many farmers have been unable to restructure their remaining farm land or find alternative income sources after joining the scheme. In 2007, the Chinese government decided to continue to pay the subsidies even after the initial contract period, but the compensation level was cut in half after the first round $[9,10]$. Under these conditions, the current article investigates the sustainability of agriculture of the farmlands involved in the GGP scheme in the Loess Plateau area.

Agricultural systems can be considered to be sustainable if they are economically viable over the long term with minimal impacts to the environment while being socially equitable [11,12]. In China, sustainable agriculture generally refers to a type of farming that ensures a balance among production (self-sufficiency), employment and income generation, natural resource management and environmental protection [13]. In previous studies with regard to sustainable agriculture on the Loess Plateau, a holistic "variation-selection-replication-retention" model was built to analyze the transformation of agricultural development from an evolutionary perspective [10]: the spatial variability of soil total nitrogen (STN) and soil total phosphorus (STP) levels as well as water use efficiencies and long-term crop rotation systems were analyzed to reflect sustainable agriculture development $[14,15]$; land suitability was evaluated and land use scenarios were simulated to explore sustainable agriculture [16]; and runoff and sediment loss as well as soil organic matter and soil nutrients were measured $[17,18]$. Although these studies shed light on agricultural sustainability, little attention has been paid to evaluating the environmental benefits, economic viability and social equity of agricultural systems in an integrative way [19-21]. Taking the case of China's Loess Hills, this study analyzes the environmental, economic and social sustainability of farming systems under the GGP environmental program.

The current study attempts to answer the following questions: (1) How can we measure the sustainability of farming systems in China's Loess Hills? (2) How is the sustainability of farming systems influenced by conservation programs such as the GGP? (3) Apart from the conservation program, how do the framework conditions affect the sustainability of farm households? As the major aim of the current work is to understand how participation in GGP programs affects farm-level sustainability, it is important to devise ways to integrate economic, social and environmental dimensions of sustainability and subsequently to analyze how GGP participation along with other critical variables such as wealth, farming skills, farm size, population, land use patterns and other social-economic conditions affect it and the constituent dimensions. In previous studies, similar sets of variables are taken into account in the analysis of technical efficiency, nitrogen losses and farm productivity [22-25]. This study advances the analysis into the aspect of sustainability of agriculture.

The following sections are organized as follows. The statistical analysis of agricultural sustainability and farm-level determinants is laid out in Section 2. Empirical results and implications are reported in Section 3. Conclusions are presented in Section 4.

\section{Methodology}

\subsection{Study Area}

Fifteen of 28 villages in Yanhe Township in Ansai County in Shaanxi Province were involved in this study. These villages are located in the hilly area and the middle part of the Loess Plateau in the north of China, with almost all farming households participating in the GGP. These 15 villages are home to 10,400 people (62\% of the population of the township), with a population density of 73 inhabitants per $\mathrm{km}^{2}$; this is typical of the Loess Hills region [26]. Yanhe Township is a good snapshot of the geographic and economic conditions prevailing in the Loess Hills. It lies between urban areas, namely $16 \mathrm{~km}$ south of the county seat and $25 \mathrm{~km}$ northwest of Yanan City. The township 
covers 210.7 square kilometres $(0.1 \%)$ of China's Loess Hills, which is a semi-arid area interlaced with hills, ravines and plains, and with an average gully density of $4.7 \mathrm{~km} / \mathrm{km}^{2}$ [27]. Annual precipitation ranges from $296.6 \mathrm{~mm}$ to $645.0 \mathrm{~mm}$ (mean $505.3 \mathrm{~mm}$ ) with a short season from July to September; annual temperature varies from $-23.6{ }^{\circ} \mathrm{C}$ to $36.8^{\circ} \mathrm{C}$ (mean $8.8^{\circ} \mathrm{C}$ ) [5,28]. Additionally, $64.4 \%$ of the population take up farming as their primary economic activity [29], on land with soils containing $60 \%$ to $70 \%$ silt, around $15 \%$ clay and $30 \%$ sand [28]. Per capita arable land is approximately 0.1 ha, which is close to the average area in China [30]; $44.3 \%$ of the arable land is used for open-field crops (e.g., potato, soybean, millet, corn, oilseed rape and sorghum), 30\% for orchard crops (e.g., apples), $4.1 \%$ for horticulture crops (e.g., chilli, cabbage, cucumber, eggplant and carrot), and $0.6 \%$ for melons (e.g., watermelon and honey melon). Per capita agricultural output of the region is RMB 8339, 40\% below the national average, of which cropping accounts for $88 \%$ and livestock production (e.g., pork and lamb) accounts for $7.5 \%[29,31]$.

\subsection{Sampling and Data Collection}

In Yanhe Township where 3390 households settle, 247 households in the 15 villages were randomly selected with a confidence interval of 6 at a 95\% confidence level. The villages surveyed cover both V-shaped valley areas (Houjiagou, Siyaoxian, Yanta, Yujiahe and Zhaiziwan in the highlands; Gaojiamao and Yayao in the middle elevations; and Zhuanyaogou and Fangjiahe in the lowlands) as well as floodplain areas (Chafang and Yunping upstream from floodplain areas; Hougoumen and Yanjiawan midstream; and Lijiawan and Yangjiagou downstream), which can be distinguished by their elevation and their distance to markets. Heads of households that account for $20 \%$ of total households in each village were personally interviewed from February to May 2014 using a standard semi-structured questionnaire. The dataset consists of household and farm characteristics as well as information from 2013 on agro-environmental and socio-economic conditions and various farm-level actions under the influence of the GGP. Additional farm-level data was generated by locating Global Positioning System coordinates of surveyed farms on the soil map from the Soil Testing and Formulated Fertilisation system, which uses Geographic Information System data and 4314 soil samples from Ansai County in 2009 [32].

\subsection{Sustainability Assessment}

\subsubsection{Selection of Sustainability Indicators}

Given our focus on the integrated sustainability assessment at the farm household scale, the present paper adopts an ex post assessment of the sustainability performance of farms using indicators and develops an indicator-based sustainability assessment schema [33]. According to literature, indicators representing multiple dimensions of sustainability are needed for a comprehensive assessment [34]. In order to identify the indicators capturing the essence of agricultural sustainability at the farm level, we applied a framework similar to the sustainability assessment of farming and environment (SAFE) by Van Cauwenbergh and others [35], considering indicators from environmental, social, and economic pillars and followed the procedure by Gómez-Limón and Sanchez-Fernandez [36] viz. data gathering, normalization of indicators, weighting indicators, and aggregation of indicators. The indicators related to the three pillars were selected based on two main factors viz. the specificity and relevance of the indicator to the sustainability of farming in the study area and the availability of data [37]. In the present paper, sustainability of farming systems is interpreted as the ability of farm households to ensure their balanced livelihoods in terms of economic viability [38,39], environmental friendliness [40,41] and physical well-being [35]. Here the three dimensions of agricultural sustainability were represented by a set of eight key indicators demonstrated below. The current approach makes sure that all dimensions of sustainability at the farm level are adequately represented with a minimum number of indicators. 


\subsubsection{Index of Farm-Household Sustainability}

Using the eight indicators, a composite index of "Farm-Household Sustainability" (FHS) was constructed. The environmental dimension is described by natural vegetation (i.e., ratio of area under forest and grass vegetation to total land area), soil organic matter (i.e., soil organic carbon at a depth $0-20 \mathrm{~cm}$, in $\mathrm{g} / \mathrm{kg}$ ), and crop diversity [42-44]. The crop diversity index (CDI) was calculated as

$$
\mathrm{CDI}=1-\sum_{\mathrm{j}=1}^{\mathrm{n}}\left(\frac{\mathrm{a}_{\mathrm{j}}}{\mathrm{A}}\right)^{2}
$$

where $a_{j}$ is the area of the $j^{\text {th }}$ crop and $A$ is the total area planted under all crops for a specific household. The index is zero for a household that grows no crops or only one crop [45].

We assumed that higher vegetation coverage, crop diversity and soil organic matter content could reduce soil and water erosion, ameliorate land degradation and restore ecosystem services over longer time periods [46-48]. The economic dimension is characterized by liquidity (i.e., current ratio $=$ current assets /current liabilities) and solvency (i.e., equity-to-asset ratio) to measure the long-term financial condition of farmers' operations [49,50]. A current ratio higher than 1 means that farmers can meet short-term debt payment obligations, whereas the higher equity-to-asset ratio indicates a less risky financial condition, as it shows how many RMB of net worth a farm has for every RMB of assets [51]. These two indicators thus can reveal the long-term financial viability of farming households. Indicators used in the social dimension are protein consumption (i.e., percentage of household protein consumption compared to what is adequate for nutrition) [52,53], education affordability (i.e., percentage of education expenditure to total household expenditure) and healthcare affordability (i.e., percentage of expenditure for health care to total household expenditure) [54,55]. This is expected to capture the long-term quality of life and health of households.

The FHS indicators are intended as a statistical construct that can support decision-making of farm households by revealing their relationships to the GGP program as well as to other spheres of influence, such as knowledge levels, demographics, economics, technology, settlement pattern, land use and social participation. The insights from the analysis are expected to generate policy suggestions [56].

\subsection{Statistical Analysis}

\subsubsection{Measurement of Farm-Household Sustainability}

The FHS index measures sustainability by aggregating the selected indicators using a weighting scheme derived from a principal component analysis (PCA). Using SPSS 13.0 [57], we performed a Kaiser-Meyer-Olkin test and Barlett's sphericity test to test the appropriateness of the PCA. For easier interpretation of the PCA results, varimax rotation was applied [58]. To obtain composite scores, Equations (2) and (3) are assigned as follows:

$$
\begin{aligned}
& \mathrm{C}_{\mathrm{ik}}=\sum_{1} \mathrm{a}_{\mathrm{k}}^{\mathrm{l}}\left(\mathrm{X}_{\mathrm{i}}^{\mathrm{l}}\right) \\
& \mathrm{S}_{\mathrm{i}}=\sum_{\mathrm{k}} \mathrm{v}_{\mathrm{k}}\left(\mathrm{C}_{\mathrm{ik}}\right)
\end{aligned}
$$

where $S_{i}$ is the composite score of sustainability of the $i^{\text {th }}$ household, $C_{i k}$ is the $k^{\text {th }}$ principal component for the $i^{\text {th }}$ household, $a_{k}^{1}$ is the loading of the $k^{\text {th }}$ component for the $1^{\text {th }}$ indicator, $v_{k}$ is the $\%$ of variance accounted by the $\mathrm{k}^{\text {th }}$ principal component, $\mathrm{X}_{\mathrm{i}}^{\mathrm{l}}$ is the standardized value of the $\mathrm{i}^{\text {th }}$ household for the $\mathrm{l}^{\text {th }}$ indicator [59]. 


\subsubsection{Impact of GGP and Framework Conditions on Sustainability: Multiple Regression Models}

In addition to key variables representing the GGP program, a broad set of indicators concerning knowledge level, demography, economics, technology, settlement pattern, land use and social participation were selected to understand how the sustainability of farm households is driven by these factors (Table 1). It is hypothesized that the FHS depends on seven broad categories of determinants: knowledge, demographics, economics, technology, settlement type, land use, and level of social participation, in addition to GGP participation.

(a) Knowledge-related variables include experience of the household in agricultural production $\left(\mathrm{H}_{1}\right)$ and the head of household's education level $\left(\mathrm{H}_{2}\right)$.

(b) Demographics-related variables include the age $\left(\mathrm{H}_{3}\right)$ and gender $\left(\mathrm{H}_{4}\right)$ of the head of household.

(c) Economic variables, which explore the role of non-farming activity in farm-household sustainability, consist of the ratio of off-farm income and subsidy to total household income $\left(\mathrm{H}_{5}\right)$.

(d) For technology, farming equipment $\left(\mathrm{H}_{6}\right)$, irrigation $\left(\mathrm{H}_{7}\right)$, electronic communication $\left(\mathrm{H}_{8}\right)$ and mulching $\left(\mathrm{H}_{9}\right)$ are used to represent households' application of farming technologies.

(e) The type of settlement, which may be decisive in access to information, cropping patterns, product prices and marketing cost, is defined by altitude $\left(\mathrm{H}_{10}\right)$ and distance to market $\left(\mathrm{H}_{11}\right)$.

(f) For land use drivers, four representative variables are used: Firstly, the ratio of land area to family work force $\left(\mathrm{H}_{12}\right)$, followed by the amount of rental land by area $\left(\mathrm{H}_{13}\right)$ and intensification regarding intercropped areas and continuously cropped areas $\left(\mathrm{H}_{14}\right)$. Finally, farmland fragmentation $\left(\mathrm{H}_{15}\right)$ is calculated using Equation (4) as follows:

$$
\mathrm{FI}=1-\left[\frac{\sum_{p} a_{p}^{2}}{\left(\sum_{p} a_{p}\right)^{2}}\right]
$$

where FI is the Simpson Index to quantify farmland fragmentation and $a_{p}$ is the area of the $\mathrm{p}^{\text {th }}$ plot of farmland for a specific household. An index of zero means that a household farms a single, contiguous plot of land fragment and that all farmland is completely consolidated [60].

(g) In order to capture the influence of the GGP program, the financial side of the program is represented by the GGP subsidy as a share of total household income $\left(\mathrm{H}_{16}\right)$ and the physical aspect is covered by the ratio of GGP land to cultivated farmland $\left(\mathrm{H}_{17}\right)$.

(h) Finally, social participation is indicated by the frequency of household members going to markets $\left(\mathrm{H}_{18}\right)$ and access for females to training and official meetings $\left(\mathrm{H}_{19}\right)$.

The paper develops multiple regression models to understand the relationship of the GGP program and identified broad categories of framework conditions to agricultural sustainability. This paper puts forth the hypothesis that there exists a threshold level of area under GGP that maximizes the farm-level sustainability. The following regression model examines how the standardized value of the composite FHS index and its three dimensions is determined by the selected indicators on participation in the GGP program and farm-level framework conditions:

$$
S_{i}^{s^{\prime}}=\sum_{j} \beta_{j}\left(H_{j}^{i}\right)+\beta_{0} \mathrm{i}=1,2,3, \ldots, I ; j=1,2,3, \ldots, J
$$

where $S_{i}^{s^{\prime}}$ is the estimated value of the standardized composite indicator of sustainability of the $\mathrm{i}^{\text {th }}$ household in terms of the environmental dimension (EnD), economic dimension (EcD), social dimension (SoD) and the composite FHS (CFHS), $\beta_{0}$ is the constant coefficient, and $\beta_{j}$ is the coefficient of $\mathrm{H}_{j}^{i}$, which is the standardized value of the $\mathrm{j}^{\mathrm{t}}$ indicators of farm-level framework conditions and GGP-related variables (including a squared term to find the threshold level if it exists) of the $\mathrm{i}^{\text {th }}$ household. 
Table 1. Indicators of GGP and farm-level framework conditions.

\begin{tabular}{|c|c|c|c|c|}
\hline \multirow{2}{*}{$\begin{array}{l}\text { Framework Conditions and } \\
\text { GGP Variables }\end{array}$} & \multirow{2}{*}{ Variables } & \multirow{2}{*}{ Description } & \multicolumn{2}{|c|}{ Descriptive } \\
\hline & & & Mean & Std. Deviation \\
\hline \multirow{2}{*}{ Knowledge } & Experience $\left(\mathrm{H}_{1}\right)$ & Number of years of experience in production concerning horticulture, orchard, livestock, off-farm, in years & 13.4 & 6.7 \\
\hline & Education level $\left(\mathrm{H}_{2}\right)$ & Number of years of head of household at school, in years & 5.9 & 3.4 \\
\hline \multirow{2}{*}{ Demographics } & Age $\left(\mathrm{H}_{3}\right)$ & Age of head of household, in years & 47.9 & 9.4 \\
\hline & Gender $\left(\mathrm{H}_{4}\right)$ & Gender of head of household is female or male, $0 / 1$ & 0.8 & 0.4 \\
\hline Economics & Non-farming income $\left(\mathrm{H}_{5}\right)^{*}$ & Ratio of off-farm income and subsidy to total household income & 0.6 & 0.3 \\
\hline \multirow{4}{*}{ Technology } & Farming equipment $\left(\mathrm{H}_{6}\right)$ & Current value of farming machines that household had, in RMB & $10,483.2$ & $27,343.3$ \\
\hline & Irrigation $\left(\mathrm{H}_{7}\right)$ & Current value of irrigation infrastructure that household had, in RMB & 465.894 & 572.904 \\
\hline & Electronic communication $\left(\mathrm{H}_{8}\right)$ & Expenditures of phone call and Internet, in RMB & 103.7 & 275.9 \\
\hline & Mulching $\left(\mathrm{H}_{9}\right)$ & Current value of mulches used on field and bags used for wrapping fruits, in RMB & 449.6 & 946.1 \\
\hline \multirow{2}{*}{ Settlement } & Altitude $\left(\mathrm{H}_{10}\right)$ & Altitude of the household, in meters & 1079.1 & 64.2 \\
\hline & Distance to market $\left(\mathrm{H}_{11}\right)$ & Distance from household place to the closest market, in $\mathrm{km}$ & 8.1 & 4.0 \\
\hline \multirow{4}{*}{ Land use } & Land/labour $\left(\mathrm{H}_{12}\right)^{*}$ & Ratio of household's land area to the work force of family labor & 0.7 & 0.5 \\
\hline & Fragmentation $\left(\mathrm{H}_{13}\right)$ & $\begin{array}{l}0-1,0 \text { means that a household farms a single, contiguous plot of land fragment and that all farmland is } \\
\text { completely consolidated }\end{array}$ & 0.6 & 0.4 \\
\hline & Intensification $\left(\mathrm{H}_{14}\right)^{\#}$ & Total area intercropped and continuously cropped, in ha & 0.2 & 0.5 \\
\hline & Land rental $\left(\mathrm{H}_{15}\right)$ & Total area of land rental including the rented and rented out land, in ha & 0.1 & 0.2 \\
\hline \multirow{3}{*}{ GGP } & Share of GGP in income $\left(\mathrm{H}_{16}\right)^{*}$ & Ratio of GGP subsidy in aggregate household income & 0.03 & 0.04 \\
\hline & GGP ratio $\left(\mathrm{H}_{17}\right)$ & Percentage of GGP land to the farmland cultivated by the household & 3.4 & 4.9 \\
\hline & Squared GGP ratio $\left(\mathrm{H}_{17}^{2}\right)$ & Sared GGP ratio & 35.3 & 132.0 \\
\hline \multirow{2}{*}{ Social participation } & Frequency to markets $\left(\mathrm{H}_{18}\right)$ & Frequency of household members going to markets for shopping or selling, in days & 14.2 & 15.2 \\
\hline & Access for females $\left(\mathrm{H}_{19}\right)$ & Females participate in training and official meetings, representing the household or not: $1 / 0$ & 0.8 & 0.4 \\
\hline
\end{tabular}

* See appendix for information about how to calculate the man-day equivalent and income; ${ }^{\#}$ Intensification of land use means more than one crops are simultaneously and sequentially planted on the same plot of farmland in one year. 


\section{Results and Discussion}

\subsection{Components of Sustainable Agriculture}

A dataset of 246 samples was used for statistical analysis after reviewing the data to check for missing values, potential errors, outliers and correlations. Eight indicators of FHS were included in the PCA, of which the Kaiser-Meyer-Olkin test and Barlett's sphericity test (see footnote for Table 2) indicate that the PCA analysis was appropriate. Four principal components were obtained, all of which contain eigenvalues greater than 1 and explain $71.6 \%$ of the variance (Table 2). The correlation between a component and indicators is called a loading, which reveals the contribution of the indicators to the variation accounted for by this component [61]. The highest loading for each variable is highlighted in bold letters; this is used as a weighting factor in constructing the index [62].

The first component (C1), which explains $24.7 \%$ of the variance, is correlated with the variables (i.e., liquidity and solvency) of the economic dimension. Thus, $\mathrm{C} 1$ represents economic viability, which is included as one of the pillars in the SAFE framework of Van Cauwenbergh and others [35] as well as the FAO/IBSRAM (International Board for Soil Research and Management) framework for the Evaluation of Sustainable Land Management (FELSM) [38]. The second component (C2), explaining $17.4 \%$ of the variance, is correlated with the environmental aspect (i.e., natural vegetation, crop diversity, soil organic matter) and hence implies the environmental dimension. The third component (C3), explaining $16.2 \%$ of the variance, is correlated with a subset of the social dimension (i.e., education affordance and healthcare affordance), while the fourth component (C4), explaining $13.2 \%$ of the variance, correlates with the variable protein consumption. Hence, C3 indicates that a household's ability to afford education and health care are correlated, whereas C4 depicts farming households' nutritional security. This reveals hidden correlations in social development. Although the PCA results provide insights into correlations among the three dimensions of FHS, the key objective here is to generate aggregating weights for the composite score of the FHS index. 
Table 2. PCA component loadings for the farm-household sustainability (FHS) index.

\begin{tabular}{|c|c|c|c|c|c|c|c|}
\hline \multirow{2}{*}{ Indicator } & \multirow{2}{*}{ Description } & \multicolumn{2}{|c|}{ Descriptive } & \multicolumn{4}{|c|}{ Principal Component } \\
\hline & & Mean & Std. Deviation & 1 & 2 & 3 & 4 \\
\hline \multicolumn{8}{|l|}{ Environmental } \\
\hline Natural vegetation & Ratio of area under forest and grass vegetation to total land area & 0.65 & 0.28 & -0.038 & -0.503 & 0.189 & 0.328 \\
\hline Crop diversity & Crop diversity index: $0-1$ & 0.44 & 0.29 & -0.092 & 0.792 & -0.171 & 0.211 \\
\hline Soil organic matter & Soil organic carbon at a depth $0-20 \mathrm{~cm}, \mathrm{in} \mathrm{g} / \mathrm{kg}$ & 9.01 & 0.27 & 0.012 & 0.688 & 0.224 & -0.123 \\
\hline \multicolumn{8}{|l|}{ Economic } \\
\hline Liquidity & Ratio of current assets to current liabilities & 3.53 & 2.43 & 0.989 & -0.039 & -0.071 & 0.025 \\
\hline Solvency & Ratio of equity to asset & 2.33 & 2.47 & 0.987 & -0.001 & -0.088 & 0.014 \\
\hline \multicolumn{8}{|l|}{ Social } \\
\hline Protein consumption & Percentage of household protein consumption to the adequate amount & 1.31 & 0.36 & 0.045 & -0.040 & 0.011 & 0.942 \\
\hline Education affordability & Percentage of education expenditure to total household expenditure & 0.10 & 0.14 & -0.123 & 0.103 & 0.788 & 0.060 \\
\hline Health affordability & Percentage of expenditure on health care to total household expenditure & 0.04 & 0.05 & 0.019 & 0.147 & -0.742 & 0.013 \\
\hline
\end{tabular}

$(p<0.001)$. 


\subsection{Determinants of Sustainable Agriculture}

Multiple regression models significantly fit the data because the $p$-value of the F-test is less than 0.0001 (Table 3). The primary aim of the analysis was to examine the relationship of the GGP program with the sustainability of farm households. The regression results show that the level of physical and economic participation in the GGP exerts significant influences. The composite score of agricultural sustainability showed an inverted U-shaped relationship with the physical share (area) of the GGP, and a negative relationship with the income share of GGP subsidies. This means that it appears that households with lower proportions of GGP subsidies as part of their annual income gain a higher level of sustainability through the economic dimension. With regard to the three dimensions, the economic $(\mathrm{EcD})$ and social dimension $(\mathrm{SoD})$ followed the inverted U-shaped relation with the physical share (area) of the GGP, but the environmental dimension (EnD) had a U-shaped relation. Threshold levels of the physical share (area) of the GGP under each dimension and for the composite indicator (CFHS) can be found by the derivative of Equations (6)-(9) of the estimated relations as follows:

$$
\begin{gathered}
\text { CFHS }^{s^{\prime}}=0.410 \mathrm{H}_{17}-0.366 \mathrm{H}_{17}^{2}+\sum_{j \neq 17} \beta_{j \neq 17}\left(\mathrm{H}_{j \neq 17}\right) \mathrm{j}=1,2,3, \ldots, 19 \\
\frac{\mathrm{d}\left(\mathrm{CFHS}^{s^{\prime}}\right)}{\mathrm{d}\left(\mathrm{H}_{17}\right)}=0.410-0.366 \times 2 \times \mathrm{H}_{17} \\
\mathrm{EcD}^{\mathrm{s}^{\prime}}=0.194 \mathrm{H}_{17}-0.183 \mathrm{H}_{17}^{2}+\sum_{j \neq 17} \beta_{j \neq 17}\left(\mathrm{H}_{j \neq 17}\right) \mathrm{j}=1,2,3, \ldots, 19 \\
\frac{\mathrm{d}\left(\mathrm{EcD}^{\mathrm{s}^{\prime}}\right)}{\mathrm{d}\left(\mathrm{H}_{17}\right)}=0.194-0.183 \times 2 \times \mathrm{H}_{17} \\
\mathrm{EnD}^{\mathrm{s}^{\prime}}=-0.202 \mathrm{H}_{17}+0.111 \mathrm{H}_{17}^{2}+\sum_{\mathrm{j} \neq 17} \beta_{\mathrm{j} \neq 17}\left(\mathrm{H}_{\mathrm{j} \neq 17}\right) \mathrm{j}=1,2,3, \ldots, 19 \\
\frac{\mathrm{d}\left(\mathrm{EnD}^{\mathrm{s}^{\prime}}\right)}{\mathrm{d}\left(\mathrm{H}_{17}\right)}=-0.202+0.111 \times 2 \times \mathrm{H}_{17} \\
\text { SoD }^{\mathrm{s}^{\prime}}=0.659 \mathrm{H}_{17}-0.518 \mathrm{H}_{17}^{2}+\sum_{\mathrm{j} \neq 17} \beta_{\mathrm{j} \neq 17}\left(\mathrm{H}_{\mathrm{j} \neq 17}\right) \mathrm{j}=1,2,3, \ldots, 19 \\
\frac{\mathrm{d}\left(\mathrm{SoD}^{\mathrm{s}^{\prime}}\right)}{\mathrm{d}\left(\mathrm{H}_{17}\right)}=0.659-0.518 \times 2 \times \mathrm{H}_{17}
\end{gathered}
$$


Table 3. Multiple regression estimates of the determinants of farm household sustainability (FHS) and three dimensions.

\begin{tabular}{|c|c|c|c|c|c|c|c|c|c|c|c|c|c|}
\hline \multirow{2}{*}{$\begin{array}{l}\text { Framework Conditions } \\
\text { and GGP Variables }\end{array}$} & \multirow{2}{*}{ Variables } & \multicolumn{3}{|c|}{ Composite FHS (CFHS) } & \multicolumn{3}{|c|}{ Economic Dimension (EcD) } & \multicolumn{3}{|c|}{ Environmental Dimension (EnD) } & \multicolumn{3}{|c|}{ Social Dimension (SoD) } \\
\hline & & Coef. $(\beta)$ & $\mathrm{SE}$ & $\mathbf{t}$ & Coef. $(\beta)$ & $\mathrm{SE}$ & $\mathbf{t}$ & Coef. $(\beta)$ & SE & $\mathbf{t}$ & Coef. $(\beta)$ & $\mathrm{SE}$ & $\mathbf{t}$ \\
\hline \multirow{2}{*}{ Knowledge } & Experience $\left(\mathrm{H}_{1}\right)$ & 0.143 & 0.064 & $2.216 * *$ & 0.054 & 0.066 & 0.820 & 0.055 & 0.051 & 1.071 & 0.140 & 0.066 & $2.126^{* *}$ \\
\hline & Education level $\left(\mathrm{H}_{2}\right)$ & 0.008 & 0.063 & 0.130 & 0.046 & 0.064 & 0.718 & -0.010 & 0.050 & -0.199 & -0.032 & 0.064 & -0.496 \\
\hline \multirow{2}{*}{ Demographics } & Age $\left(\mathrm{H}_{3}\right)$ & 0.027 & 0.068 & 0.392 & 0.180 & 0.070 & $2.558 * *$ & 0.121 & 0.055 & $2.202 * *$ & -0.265 & 0.070 & $-3.778^{* *}$ \\
\hline & Gender $\left(\mathrm{H}_{4}\right)$ & -0.007 & 0.062 & -0.111 & -0.032 & 0.064 & -0.503 & 0.014 & 0.050 & 0.284 & 0.014 & 0.064 & 0.219 \\
\hline Economics & Non-farming income $\left(\mathrm{H}_{5}\right)^{*}$ & 0.087 & 0.071 & 1.215 & 0.269 & 0.073 & $3.669^{* *}$ & -0.012 & 0.057 & -0.207 & -0.155 & 0.073 & $-2.121 * *$ \\
\hline \multirow{4}{*}{ Technology } & Farming equipment $\left(\mathrm{H}_{6}\right)$ & -0.043 & 0.068 & -0.630 & -0.006 & 0.070 & -0.086 & -0.005 & 0.055 & -0.090 & -0.064 & 0.070 & -0.916 \\
\hline & Irrigation $\left(\mathrm{H}_{7}\right)$ & -0.062 & 0.068 & -0.912 & -0.035 & 0.070 & -0.494 & 0.045 & 0.055 & 0.820 & -0.105 & 0.070 & -1.507 \\
\hline & Electronic communication $\left(\mathrm{H}_{8}\right)$ & -0.055 & 0.059 & -0.943 & -0.088 & 0.060 & -1.464 & -0.033 & 0.047 & -0.711 & 0.035 & 0.060 & 0.578 \\
\hline & Mulching $\left(\mathrm{H}_{9}\right)$ & 0.364 & 0.071 & $5.134^{* *}$ & 0.247 & 0.073 & $3.390^{* *}$ & 0.165 & 0.057 & $2.902^{* *}$ & 0.210 & 0.073 & $2.894^{* *}$ \\
\hline \multirow{2}{*}{ Settlement } & Altitude $\left(\mathrm{H}_{10}\right)$ & 0.089 & 0.124 & 0.723 & -0.006 & 0.127 & -0.051 & 0.150 & 0.099 & 1.508 & 0.040 & 0.127 & 0.318 \\
\hline & Distance to market $\left(\mathrm{H}_{11}\right)$ & -0.146 & 0.106 & -1.381 & -0.296 & 0.109 & $-2.729 * *$ & 0.110 & 0.085 & 1.294 & 0.003 & 0.108 & 0.023 \\
\hline \multirow{4}{*}{ Land use } & Land/labour $\left(\mathrm{H}_{12}\right)^{*}$ & -0.145 & 0.083 & -1.747 * & 0.055 & 0.085 & 0.643 & -0.121 & 0.067 & $-1.806 *$ & -0.220 & 0.085 & $-2.578 * *$ \\
\hline & Fragmentation $\left(\mathrm{H}_{13}\right)$ & 0.183 & 076 & $2.400 * *$ & 0.040 & 0.078 & 0.515 & 0.323 & 0.061 & $5.286 * *$ & 0.006 & 0.078 & 0.071 \\
\hline & Intensification $\left(\mathrm{H}_{14}\right) \#$ & 0.084 & 0.067 & 1.258 & -0.051 & 0.068 & -0.741 & 0.154 & 0.053 & 2.886 ** & 0.079 & 0.068 & 1.157 \\
\hline & Land rental $\left(\mathrm{H}_{15}\right)$ & 0.055 & 0.061 & 0.896 & 0.061 & 0.063 & 0.973 & 0.036 & 0.049 & 0.732 & -0.006 & 0.063 & -0.091 \\
\hline \multirow{3}{*}{ GGP } & Share of GGP in income $\left(\mathrm{H}_{16}\right) *$ & -0.255 & 0.074 & $-3.460 * *$ & -0.271 & 0.076 & $-3.578^{* *}$ & -0.004 & 0.059 & -0.072 & -0.124 & 0.076 & -1.642 \\
\hline & GGP ratio $\left(\mathrm{H}_{17}\right)$ & 0.410 & 0.137 & $2.999 * *$ & 0.194 & 0.141 & 1.380 & -0.202 & 0.110 & $-1.839^{*}$ & 0.659 & 0.140 & $4.690^{* *}$ \\
\hline & Squared GGP ratio $\left(\mathrm{H}_{17}^{2}\right)$ & -0.366 & 0.129 & -2.835 ** & -0.183 & 0.133 & -1.383 & 0.111 & 0.104 & 1.068 & -0.518 & 0.133 & $-3.907^{* *}$ \\
\hline \multirow{2}{*}{ Social participation } & Frequency to markets $\left(\mathrm{H}_{18}\right)$ & 0.018 & 0.069 & 0.258 & 0.116 & 0.071 & 1.633 & 0.046 & 0.056 & 0.831 & -0.144 & 0.071 & $-2.026^{* *}$ \\
\hline & Access for females $\left(\mathrm{H}_{19}\right)$ & 0.110 & 0.061 & 1.810 * & 0.067 & 0.063 & 1.071 & 0.119 & 0.049 & $2.446 * *$ & 0.015 & 0.062 & 0.245 \\
\hline Constant & & 0.000 & 0.056 & 0.000 & 0.000 & 0.057 & 0.000 & 0.000 & 0.045 & 0.000 & 0.000 & 0.057 & 0.000 \\
\hline
\end{tabular}

${ }^{*}{ }^{* *}=0.1$ and 0.05 significance levels, respectively; observation: 246; Model of FHS: $\mathrm{F}=4.733 ;$ prob $>\mathrm{F}=0.0001 ; R^{2}=0.296 ;$ Model of Economic Dimension: $\mathrm{F}=3.903 ;$ prob $>\mathrm{F}=0.0001$; $R^{2}=0.258$; Model of Environmental Dimension: $\mathrm{F}=13.571$; prob $>\mathrm{F}=0.0001 ; R^{2}=0.547$; Model of Social Dimension: $\mathrm{F}=3.920 ;$ prob $>\mathrm{F}=0.0001 ; R^{2}=0.258 ; *$ See appendix for information about how to calculate the man-day equivalent and income; \# Intensification of land use means more than one crop are simultaneously and sequentially planted on the same plot of farmland in one year. Model validity is proved by the supplementary materials. 
Setting the derivatives equal to zero, the turning points of the CFHS and its three dimensions were calculated for GGP variables. Thus, agricultural sustainability would be at its maximum if the ratio of the GGP land to farmland were to remain at 0.56 , while its social dimension would be the best if it were to remain at 0.64 . The thresholds levels of economic and environmental dimensions are insignificant, but they show that the economic dimension requires a ratio of 0.53 and the environmental dimension demands a ratio below 0.91. However, the current GGP ratio is close to 3.38, as an average of set-aside (GGP) land is around 1.79 ha while mean farmland area is only 0.53 ha per household. This emphasizes the need to adjust the proportion of GGP land to farmland for enhancing the sustainability of farm households under the set-aside program. Our analysis suggests limiting the physical share of GGP to around 0.6. It is to be noted that the GGP in Northern China has already been criticized for the retirement of productive and low-sloped land [4].

In the case of the economic dimension, non-farming income (economic variable) has no significant influence on the CFHS and $\mathrm{EnD}$, but positively affects the $\mathrm{EcD}$ and negatively affects the SoD at a significant level. This serves as a warning that non-farm production (contract jobs and casual employment in non-farm sectors in peri-urban or urban areas) is not a sufficient condition for sustainable agriculture in the Loess Hills, but it does nevertheless improve households' economic situation. Non-farming activity is recommended for GGP-participating households to raise production and income [7]. A labor shift away from agriculture to other economic sectors has been promoted to diversify income sources and increase farm size in rural China [63]. Nevertheless, the non-farming activity undermines households' social situation as farmers suffer from a lack of assets and capacity $[7,64]$. The high fixed costs involved in non-farming production shrink households' investments in food, education and health care. A combination of credit constraints and high transaction costs of information-sharing also discourages farmers from taking up non-farming activities $[65,66]$.

In the case of demographics and settlement-related variables, the CFHS is not significantly influenced by them. However, the age of the head of household has significant positive effects on the $\mathrm{EcD}$ and EnD, but a negative effect on the SoD. This may be due to the fact that households with an older head possess more assets and social networks for information and credit to improve production and environment, but they are also more risky in terms of long-term health. In addition, the distance of settlements to markets has a significant negative effect on the $\mathrm{EcD}$. This proves that providing access to markets would confer substantial economic benefits on households [67]. The analysis does not suggest any significant difference between male- and female-headed households as well as households settled in various altitudes regarding sustainability. It should be noted that female-headed households and high-land settlements may have less access to natural and financial resources, but the result shows that women and highlands are on a par (or superior) in developing household sustainability compared to men and lowlands under existing conditions.

With regard to knowledge and technology, farmers' experience and their use of mulches have significant effects. This means that households with more experience in production perform better in household sustainability, particularly in the social situation. This appreciates the fact that farmers' experience is often associated with the adoption of sustainable techniques and practices [68] which can help households improve the quality of their life and the sustainability. Households using techniques such as mulches and fruit bags (for apples) perform better in sustainability in all three dimensions. Mulching is an effective way to increase carbon sequestration of soils, to improve weed control, to conserve soil and to enhance crop yield in northwestern China [69-72]. Fruit bagging can improve fruit coloring and flesh quality [73], raising economic returns. In addition, the analysis does not suggest any significant effects from the education level, farming equipment, irrigation and electronic communication. This may be due to their homogenous levels in the Loess Hills (Table 3). Additionally, the use of large amounts of equipment, fertilizers, pesticides and irrigation may have the potential to make agricultural systems dependent on high energy consumption and unsustainable [74]. 
In the case of land use, all variables have significant influences except the total area of rental land. This can be explained by the low incidence of land rental transactions in rural China [75,76]. The ratio of land to labor has significant negative effects on the CFHS, EnD and SoD; farmland fragmentation has positive effects on the CFHS and the EnD; and farmland intensification has positive effects on the EnD. Such information implies that the small fragmented farm (as shown in Table 1, means of Land/labor and Fragmentation Index are higher than 0.60) does not significantly contribute to the economic dimension, but benefits household sustainability through environmental and social dimensions. From a sustainability perspective, a small efficient farm is the most sustainable (at lower income levels) pattern due to its fewer off-farm inputs and higher biotic diversity [77]. A high land-to-labor ratio can push down the marginal benefit from labor and thus decrease income per hectare [78] while intercropping and continuous cropping in plots can ensure vegetation coverage of farmland for soil and water conservation [74] as well as increase economic returns within a farming year.

With respect to social participation, access for females to training has significant effects on the CFHS and EnD. It shows that female participation plays a great role in environmental protection with regard to building the sustainability of agricultural systems. Another study also argued that farm production could improve if women learn more about farming practices [79]. In addition, the frequency of farmers going to markets has no significant effect on the CFHS, but a negative one on the SoD. This indicates that the current system of markets could neither significantly trigger income increase nor improve the economic situation. On the contrary, frequent trips to the market seem to be a burden on households, deteriorating the quality of their life. The benefits of physical access to markets for producers may be offset by the low selling price of agricultural products or high costs of transport.

\subsection{Summary and Implications}

The study was intended to understand the sustainability of farm households under the GGP conservation program in the Loess Hills in China. In order to operationalize the concept of farm household sustainability, a composite index was formulated regarding economic, environmental and social dimensions. The principal component analysis was applied to reveal the latent structure and internal correlations among indicators and generate a weighting scheme for the composite index. The generated PCA components explain sustainable agriculture in terms of environmental conservation, economic viability, physical well-being (i.e., affordability of education and health care), and food security [35]. Thus, the composite scores of farm household sustainability and its dimensions can reveal the expected relation of agricultural sustainability of farming households to GGP and other determinants.

The regression models highlight that the ratio of GGP land to farmland is a major determinant of agricultural sustainability in the study area and that the ability of farm households to diversify into non-farm enterprises can substantially enhance their economic viability. It is necessary to adjust the proportion of GGP land and reallocate labor between "on-farm" to "off-farm" work. This may promote agricultural production, diversify income sources, and hence improve the sustainability of agricultural households. There is also a need for an improved system of markets and cheaper transport to markets, schools and hospital facilities in order to support the household's attempts to increase its sustainability. Increased access to information and credit for farmers can empower farmers to be more active in production, processing and marketing. Skills training and life-long education [80], especially female participation, are necessary for the dissemination of knowledge and the accumulation of experience in enhancing production and building sustainable farm households.

The study also reveals a positive relationship between farm fragmentation and socio-environmental sustainability [81]. This result can be related to the European experiences that land consolidation as an isolated tool may trigger unfavorable side-effects on rural development in transitional environments [82]. Given the existing conditions of imperfect land markets, sustainably intensifying cultivation of remaining farming land (e.g., intercropping of apple trees and beans, continuous cropping 
of vegetables and melons) by applying agronomic techniques (e.g., plastic mulching, fruit bagging) and a labor shift toward non-farm production can help foster the sustainable agriculture of China's Loess Hills in the medium term.

\section{Conclusions}

Using the techniques of dimensionality reduction, the multi-dimensional concept of farm-level sustainability is captured, adopting an indicator-based sustainability assessment schema, and the relevance of the conservation program (land set-aside) on the sustainability of farm households in the Loess Hills of China is revealed through a follow-up regression of relevant variables. The share of the area of set-aside (GGP) land as a proportion of the total farmland proved to be the key determinant of agricultural sustainability. Inverted U-shaped relationships between the share of GGP and the composite index of sustainability and its social dimension were revealed. Moreover, relationships between the share of GGP land and its economic and environmental dimensions were also probed. This led to the conclusion that there is a threshold of the physical (area) share of the GGP that eventually determines agricultural sustainability in terms of economic viability, environmental benefits and social welfare. Further analysis revealed how the selected physical-socio-economic-infrastructural-technological framework variables exerted different levels of influence on various dimensions of sustainability and hence highlighted the need to understand the individual pillars of sustainability along with the composite one to find out about trade-offs. In the study area, a small farm size, land fragmentation and imperfect land markets restrain households' agro-economic production and their adaptation of socially and environmentally sound practices. Therefore, increasing the share of farmland relative to set-aside land towards the threshold level, training female farmers in environmentally friendly farming practices, providing financial services to diversify the enterprises of farmers, encouraging agronomic practices such as mulching, and providing better market facilities can lead to a path towards more sustainable agricultural systems in the study area. Our study thus provides a number of insights on land restoration and set-aside programs for further research. Some limitations also need to be considered. While the currently built index can measure sustainability encompassing three dimensions, more profound insights could be brought with a broader set of indicators and different scenarios concerning land and labor allocation, technical innovation and others.

Supplementary Materials: The following are available online at www.mdpi.com/2071-1050/8/4/395/s1, Figure S1: Histogram of residual normality test. (a) Sustainability (CFHS); (b) Economic dimension (EcD); (c) Environmental dimension (EnD); (d) Social dimension (SoD). Figure S2: Residual normality test. (a) Sustainability (CFHS); (b) Economic dimension (EcD); (c) Environmental dimension (EnD); (d) Social dimension (SoD). Table S1: Residuals statistics for residual normality test of the regression models. Table S2: Robustness test of the regression models.

Acknowledgments: The authors acknowledge the work of the research assistants in data collection and analysis. We are also grateful to all of the farmers who cooperated in the household surveys and provided data.

Author Contributions: Qirui Li prepared the data and wrote the paper. T.S. Amjath-Babu and Peter Zander contributed to the research design and statistical analysis. Zhen Liu and Klaus Müller assisted with the research. All the authors revised the manuscript and approved the final version.

Conflicts of Interest: The authors declare no conflict of interest.

\section{Appendix}

In our study, the total active work force in man-day equivalents and family labor in per-capita equivalents were calculated by applying conversion factors to male and female household members in different age groups as follows: 1.0 for males aged between 16 and 60 years; 0.75 for females between 16 and 60 years; 0.75 for males above 60 years; 0.5 for females above 60 years. Household members below 16 and above 70 years of age were not considered. In addition, income gained from off-farm work, open-field crop, horticulture and GGP compensation was considered per family labor workforce 
and by farm price rather than market price. For the sake of current value, in addition, annuity was used for orchard income and livestock income by calculating inputs and outputs over their lifetime.

\section{References}

1. Cao, S.X. Impact of China's Large-Scale Ecological Restoration Program on the Environment and Society in Arid and Semiarid Areas of China: Achievements, Problems, Synthesis, and Applications. Crit. Rev. Environ. Sci. Technol. 2011, 41, 317-335. [CrossRef]

2. Bennett, M.T. China's sloping land conversion program: Institutional innovation or business as usual? Ecol. Econ. 2008, 65, 699-711. [CrossRef]

3. Liu, J.; Li, S.X.; Ouyang, Z.Y.; Tam, C.; Chen, X.D. Ecological and socioeconomic effects of China's policies for ecosystem services. Proc. Natl. Acad. Sci. USA 2008, 105, 9477-9482. [CrossRef] [PubMed]

4. Cao, S.X.; Xu, C.G.; Li, C.; Wang, X.Q. Attitudes of farmers in China's northern Shaanxi Province towards the land-use changes required under the Grain for Green Project, and implications for the project's success. Land Use Policy 2009, 26, 1182-1194. [CrossRef]

5. Lu, C.H.; Van Ittersumb, M.K.; Rabbinge, R. A scenario exploration of strategic land use options for the Loess Plateau in northern China. Agric. Syst. 2004, 79, 145-170. [CrossRef]

6. Guo, Y.J.; Liu, Y.S.; Wen, Q.; Li, Y.R. The transformation of agricultural development towards a sustainable future from an evolutionary view on the Chinese Loess Plateau: A case study of Fuxian County. Sustainability 2014, 6, 3644-3668. [CrossRef]

7. Liang, Y.C.; Li, S.H.; Feldman, M.W.; Daily, G. Does household composition matter? The impact of the Grain for Green Program on rural livelihoods in China. Ecol. Econ. 2012, 75, 152-160. [CrossRef]

8. Liu, C.; Wu, B. Grain for Green Program in China: Policy Making and Implementation? Available online: https://www.nottingham.ac.uk/cpi/documents/briefings/briefing-60-reforestation.pdf (accessed on 20 April 2016).

9. Tang, X.L. China's ecological restoration programs and policy. In Proceedings of the International Symposium on Evaluating China's Ecological Restoration Programs, Beijing, China, 19 October 2007.

10. Bullock, A.; King, B. Evaluating China's slope land conversion program as sustainable management in Tianquan and Wuqi Counties. J. Environ. Manag. 2011, 92, 1916-1922. [CrossRef] [PubMed]

11. Lichtfouse, E.; Navarrete, M.; Debaeke, P.; Souchere, V.; Alberola, C.; Menassieu, J. Agronomy for sustainable agriculture. A review. In Agronomy for Sustainable Development; Springer Verlag: Berlin, Germany, 2009; Volume 29, pp. 1-6.

12. Hermanns, T.; Helming, K.; Schmidt, K.; Koenig, H.J.; Faust, H. Stakeholder strategies for sustainability impact assessment of land use scenarios: Analytical framework and identifying land use claims. Land 2015, 4, 778-806. [CrossRef]

13. Liu, L. Sustainability: Living within one's own ecological means. Sustainability 2009, 1, 1412-1430. [CrossRef]

14. Wang, Y.Q.; Zhang, X.C.; Huang, C.Q. Spatial variability of soil total nitrogen and soil total phosphorous under different land uses in a small watershed on the Loess Plateau, China. Geoderma 2009, 150, 141-149. [CrossRef]

15. Huang, M.B.; Shao, M.A.; Zhang, L.; Li, Y.S. Water use efficiency and sustainability of different long-term crop rotation systems in the Loess Plateau of China. Soil Tillage Res. 2003, 72, 95-104. [CrossRef]

16. Chen, L.D.; Messing, I.; Zhang, S.R.; Fu, B.J.; Ledin, S. Land use evaluation and scenario analysis towards sustainable planning on the Loess Plateau in China-case study in a small catchment. Catena 2003, 54, 303-316. [CrossRef]

17. Wang, J.; Fu, B.J.; Qiu, Y.; Chen, L.D. Analysis on soil nutrient characteristics for sustainable land use in Danangou catchment of the Loess Plateau, China. Catena 2003, 54, 17-29. [CrossRef]

18. Kang, S.Z.; Zhang, L.; Song, X.Y.; Zhang, S.H.; Liu, X.Z.; Liang, Y.L.; Zheng, S.Q. Runoff and sediment loess responses to rainfall and land use in two agricultural catchments on the Loess Plateau of China. Hydrol. Process. 2001, 15, 977-988. [CrossRef]

19. Demattini, E.; Gaviglio, A.; Bertoni, D. Integrating agricultural sustainability into policy planning: A geo-referenced framework based on Rough Set theory. Environ. Sci. Policy 2015, 54, 226-239. [CrossRef] 
20. Haileslassie, A.; Craufurd, P.; Thiagarajah, R.; Kumar, S.; Whitbread, A.; Rathor, A.; Blummel, M.; Ericsson, P.; Kakumanu, K.R. Empirical evaluation of sustainability of divergent farms in thedryland farming systems of India. Ecol. Ind. 2016, 60, 710-723. [CrossRef]

21. Paracchini, M.L.; Bulgheroni, C.; Borreani, G.; Tabacco, E.; Banterle, A.; Bertoni, D.; Rossi, G.; Parolo, G.; Origgi, R.; De Paola, C. A diagnostic system to assess sustainability at a farm level: The SOSTARE model. Agric. Syst. 2015, 133, 35-53. [CrossRef]

22. Assuncao, J.J.; Ghatak, M. Can unobserved heterogeneity in farmer ability explain the inverse relationship between farm size and productivity. Econ. Lett. 2003, 80, 189-194. [CrossRef]

23. Dalgaard, T.; Hutchings, N.; Dragosits, U.; Olesen, J.E.; Kjeldsen, C.; Drouet, J.L.; Cellier, P. Effects of farm heterogeneity and methods for upscaling on modeled nitrogen losses in agricultural landscapes. Environ. Pollut. 2011, 159, 3183-3192. [CrossRef] [PubMed]

24. Heshmati, A.; Kumbhakar, S.C. Farm heterogeneity and technical efficiency: Some results from Swedish dairy farms. J. Prod. Anal. 1994, 5, 45-61. [CrossRef]

25. Hockmann, H.; Pieniadz, A. Farm heterogeneity and efficiency in Polish agriculture: A stochastic analysis. In 10th (Joint) EAAE-IAAE Seminar Agricultural Economics and Transition: "What Was Expected, What We Observed, the Lessons Learned"; Corvinus University of Budapest (CUB): Budapest, Hungary, 2007.

26. Liu, Y.H.; Xu, Y.; Liu, Y. Population growth and temüoral-spatial defferentiation in Loess Plateau region in the last 2000 years. Prog. Geogr. 2012, 31, 156-166. (In Chinese)

27. Xu, Y.; Tang, Q.; Zhang, T.; Yang, Q. Influence of Ecological Defarming Scenarios on Agriculture in Ansai County, Loess Plateau, China. Mount. Res. Dev. 2009, 29, 36-45.

28. Lu, C.H.; Van Ittersum, M.K.; Rabbinge, R. Quantitative assessment of resource-use efficient cropping systems: A case study for Ansai in the Loess Plateau of China. Eur. J. Agron. 2003, 19, 311-326. [CrossRef]

29. Ansai Statistical Bureau. Statistical Yearbook of Ansai County, 2012; Ansai Statistical Bureau: Shaanxi, China, 2013. (In Chinese).

30. Lichtenberg, E.; Ding, C.R. Local officials as land developers: Urban spatial expansion in China. J. Urban Econ. 2009, 66, 57-64. [CrossRef]

31. National Bureau of Statistics of China. China Statistical Yearbook, 2013; China Statistics Press: Beijing, China, 2014.

32. Ansai Agro-Tech Extension and Service Station. Cultivated Land Quality Evaluation System; Ansai Agro-Tech Extension and Service Station: Shaanxi, China, 2010. (In Chinese)

33. De Olde, E.M.; Oudshoorn, F.W.; Sorensen, C.A.G.; Bokkers, E.A.M.; de Boer, I.J.M. Assessing sustainability at farm-level: Lessons learned from a comparison of tools in practice. Ecol. Ind. 2016, 66, 391-404. [CrossRef]

34. Smith, C.S.; McDonald, G.T. Assessing the sustainability of agriculture at the planning stage. J. Environ. Manag. 1998, 52, 15-37. [CrossRef]

35. Van Cauwenbergh, N.; Biala, K.; Bielders, C.; Brouckaert, V.; Franchois, L.; Cidad, V.G.; Hermy, M.; Mathijs, E.; Muys, B.; Reijnder, J.; et al. SAFE-A hierarchical framework for assessing the sustainability of agricultural systems. Agric. Ecosyst. Environ. 2007, 120, 229-242. [CrossRef]

36. Gómez-Limón, J.A.; Sanchez-Fernandez, G. Empirical evaluation of agricultural sustainability using composite indicators. Ecol. Econ. 2010, 69, 1062-1075. [CrossRef]

37. Manos, B.; Bournaris, T.; Chatzinikolaou, P.; Berbel, J.; Nikolov, D. Effects of CAP policy on farm household behavior and social sustainability. Land Use Policy 2013, 31, 166-181. [CrossRef]

38. Tisdell, C. Economic indicators to assess the sustainability of conservation farming projects: An evaluation. Agric. Ecosyst. Environ. 1996, 57, 117-131. [CrossRef]

39. Ghebremichael, L.T.; Veith, T.L.; Hamlett, J.M. Integrated watershed- and farm-scale modeling framework for targeting critical source areas while maintaining farm economic viability. J. Environ. Manag. 2013, 114, 381-394.

40. Galan, M.B.; Peschard, D.; Boizard, H. ISO 14001 at the farm level: Analysis of five methods for evaluating the environmental impact of agricultural practices. J. Environ. Manag. 2013, 82, 341-352. [CrossRef] [PubMed]

41. Kleinhanss, W.; Murillo, C.; Juan, C.S.; Sperlich, S. Efficiency, subsidies, and environmental adaptation of animal farming under CAP. Agric. Econ. 2007, 36, 49-65. [CrossRef]

42. Scherr, S.J.; McNeely, J.A. Biodiversity conservation and agricultural sustainability: Towards a new paradigm of 'ecoagriculture' landscapes. Philos. Trans. R. Soc. B 2008, 363, 477-494. [CrossRef] [PubMed]

43. Magdoff, F.; Weil, R.R. Soil Organic Matter in Sustainable Agriculture; CRC Press: Boca Raton, FL, USA, 2004. 
44. Lyson, A.T.; Welsh, R. The production function, crop diversity, and the debate between conventional and sustainable agriculture. Rural Sociol. 1993, 58, 424-439. [CrossRef]

45. Shahidullah, S.M.; Talukder, M.S.A.; Kabir, M.S.; Kahn, A.H.; Elahi, N.E. Cropping patterns in the south east coastal region of Bangladesh. J. Agric. Rural Dev. 2006, 4, 53-60. [CrossRef]

46. Mahmoudzadeh, A. Vegetation cover plays the most important role in soil erosion control. Pak. J. Biol. Sci. 2007, 10, 388-392. [CrossRef] [PubMed]

47. Di Falco, S.; Bezabin, M.; Yesuf, M. Seeds for livelihood: Crop biodiversity and food production in Ethiopia. Ecol. Econ. 2010, 69, 1695-1702. [CrossRef]

48. Mulongoy, K.; Merckx, R. Soil Organic Matter Dynamics and Sustainability of Tropical Agriculture; John Wiley and Sons: New York, NY, USA, 1993; pp. 3-18.

49. Hanson, J.C.; Johnson, D.M.; Peters, S.E.; Janke, R.R. The productivity of sustainable agriculture on a representative grain farm in the Mid-Atlantic region, 1981-89. Profitabil. Sustain. Agric. 1990, 2, 90-98.

50. Bostan, I. Assessing the risk for the agriculture exploitations entitles and monitoring the liquidity and solvency in accounting. Bull. UASVM Hortic. 2008, 65, 53-58.

51. Plastina, A. Finacial performance measures for Iowa farms. In Ag Decision Maker; Department of Economics University Extension, Iowa State University: Ames, IA, USA, 2015.

52. Food and Agriculture Organization of the United Nations (FAO). Food composition table for use in East Asia. In Food Policy and Nutrition Division; FAO: Rome, Italy, 1972; p. 334.

53. Food and Agriculture Organization of the United Nations (FAO). World Livestock 2011-Livestock in Food Security; FAO: Rome, Italy, 2011.

54. McPherson, S. Education and Sustainability Learning Across the Diaspora, Indigenous and Minority Divide; Routledge: New York, NY, USA, 2011.

55. Desha, C.; Hargroves, K.C. Higher Education and Sustainable Development: A Model for Curriculum Renewal; Routledge: London, UK, 2014.

56. Hennessy, T.; Buckley, C.; Dillon, E.; Donnellan, T.; Hanrahan, K.; Moran, B.; Ryan, M. Measuring Farm Level Sustainability with the Teagasc National Farm Survey; Teagasc: Athenry, Ireland, 2013.

57. SPSS Inc. SPSS 13.0 Guide to Data Analysis; Prentice Hall: Chicago, IL, USA, 2005.

58. Bidogeza, J.C.; Berentsen, P.B.M.; Graaff, J.D.; Oude Lansink, A.G.J.M. A typology of farm households for the Umutara Province in Rwanda. Food Secur. 2009, 1, 321-335. [CrossRef]

59. Mutabazi, K.D.; Amjath-Babu, T.S.; Sieber, S. Influence of livelihood resources on adaptive strategies to enhance climatic resilience of farm households in Morogoro, Tanzania: An indicator-based analysis. Reg. Environ. Chang. 2015, 15, 1259-1268. [CrossRef]

60. Monchuk, D.; Deininger, K.; Nagarajan, H. Does land fragmentation reduce efficiency: Micro evidence from India. In Proceedings of the Agricultural \& Applied Economics Association 2010 AAEA, CAES, \& WAEA Joint Annual Meeting, Dever, CO, USA, 25-27 July 2010.

61. Dossa, L.H.; Abdulkadir, A.; Amadou, H.; Sangare, S.; Schlecht, E. Exploring the diversity of urban and peri-urban agricultural systems in Sudano-Sahelian West Africa: An attempt towards a regional typology. Landsc. Urban Plan. 2011, 102, 197-206. [CrossRef]

62. Costantini, P.; Linting, M.; Porzio, G.C. Mining performance data through nonlinear PCA with optimal scaling. Appl. Stoch. Models Bus. Ind. 2010, 26, 85-101. [CrossRef]

63. Heilig, G.K. Can China Feed Itself? In A System for Evaluation of Policy Options, CD-ROM Version 1.1; International Institute for Applied Systems Analysis (IIASA): Laxenburg, Austria, 1999.

64. Reardon, T. Rural Non-Farm Income in Developing Countries; Food and Agriculture Organization of the United Nations (FAO): Rome, Italy, 1998.

65. Uchida, E.; Rozelle, S.; Xu, J.T. Conservation payments, liquidity constraints and off-farm labor: Impact of the Grain for Green Program on rural households in China. Am. J. Agric. Econ. 2009, 91, 70-86. [CrossRef]

66. Han, L.H.; Hare, D. The link between credit markets and self-employment choice among households in rural China. J. Asian Econ. 2013, 26, 52-64. [CrossRef]

67. Jacoby, H.G. Access to markets and the benefits of rural roads. Econ. J. 2000, 110, 713-737. [CrossRef]

68. Lee, R.D. Agricultural sustainability and technology adoption: Issues and policies for developing countries. Am. J. Agric. Econ. 2005, 87, 1325-1334. [CrossRef]

69. Carter, M.R. Conservation Tillage in Temperate Agroecosystems; Lewis: Boca Raton, FL, USA, 1994. 
70. Li, Z.; Tian, C.; Zhang, R.; Mohamed, I.; Liu, Y.; Zhang, G.; Pan, J.; Chen, F. Plastic mulching with drip irrigation increases soil carbon stocks of natrargid soils in arid areas of northwestern China. Catena 2015, 133, 179-185. [CrossRef]

71. Zhou, L.M.; Zhang, F.; Liu, C.A. Improved yield by harvesting water with ridges and subgrooves using buried and surface plastic mulches in a semiarid area of China. Environ. Health Perspect. 2002, 110, 445-456.

72. Campiglia, E.; Mancinelli, R.; Radicetti, E.; Caporali, F. Effect of cover crops and mulches on weed control and nitrogen fertilization in tomato. Crop Protect. 2010, 29, 354-363. [CrossRef]

73. Huang, C.H.; Yu, B.; Teng, Y.W.; Su, J.; Shu, Q.; Cheng, Z.Q.; Zeng, L.Q. Effects of fruit bagging on coloring and related physiology, and qualities of red Chinese sand pears during fruit maturation. Sci. Hortic. 2009, 121, 149-158. [CrossRef]

74. Pimentel, D.; Harvey, C.; Resosudarmo, P.; Sinclair, K.; Kurz, D.; McNair, M.; Crist, S.; Shpritz, L.; Saffouri, R.; Blair, R. Environmental and economic costs of soil erosion and conservation benefits. Sci. New Ser. 1995, 267, 1117-1123. [CrossRef] [PubMed]

75. You, H.Y. Effect of farmland regulation on farmland rental in China: An empirical study of peasant households. Adv. Inf. Sci. Serv. Sci. 2012, 4, 467-476.

76. Kung, J.K.S. Off-farm labor markets and the emergence of land rental markets in rural China. J. Comp. Econ. 2002, 30, 395-414. [CrossRef]

77. Horrigan, L.; Lawrence, R.S.; Walker, P. How sustainable agriculture can address the environmental and human health harms of industrial agriculture. Environ. Health Perspect. 2002, 110, 445-456. [CrossRef] [PubMed]

78. Eswaran, M.; Kotwal, A. Access to Capital and Agrarian Production Organisation. Econ. J. 1986, 96, 482-498. [CrossRef]

79. Chen, S.J.; Wang, Y.; Wang, Y.J. The Loess Plateau watershed rehabilitation project: A case study from reducing poverty, sustaining growth—“What works, What doesn't, and Why”. In Proceedings of the Scaling Up Poverty Reduction: A Global Learning Process and Conference, Shanghai, China, 25-27 May 2004.

80. Praendl-Zika, V. From subsistence farming towards a multifunctional agriculture: Sustainability in the Chinese rural reality. J. Environ. Manag. 2008, 87, 236-248. [CrossRef] [PubMed]

81. Deininger, K.; Jin, S.Q. The potential of land rental markets in the process of economic development: Evidence from China. J. Dev. Econ. 2005, 78, 241-270. [CrossRef]

82. Djanibekov, N.; van Assche, K.; Bobojonov, I.; Lamersa, J.P.A. Farm restructuring and land consolidation in Uzbekistan: New farms with old barriers. Eur. Asia Stud. 2012, 64, 1101-1126. [CrossRef] 